\title{
Developing Online Portal for Vocational High School Based on Geographic Information System (Gis) As the Communication and Information Media
}

\author{
MH. Fahd Al Aliem Romas and Priyanto
}

Department of Industrial Engineering, Postgraduate School, Universitas Islam Indonesia

\section{Abstract}

This study aims at developing an online portal (1) to deliver information about vocational high schools (VHS) and its expertise programs (2) to convey information about VHS and its supporting data (3) to allow users to share information and communicate with the school. This research employed Research and Development to create VHS online portal based on Geographic Information System (GIS). This study was preceded by the literature study to obtain the data from books, printed media, journals, scientific articles, government regulations, laws and various electronic media. The result of this

Corresponding Author: $\mathrm{MH}$. Fahd Al Aliem Romas mh.fahd2015@student.uny.ac.id

Received: 16 September 2019 Accepted: 28 September 2019 Published: 31 October 2019 Publishing services provided by Knowledge E

(c) $\mathrm{MH}$. Fahd Al Aliem Romas and Priyanto. This article is distributed under the terms of the Creative Commons

Attribution License, which permits unrestricted use and redistribution provided that the original author and source are credited.

Selection and Peer-review under the responsibility of the ICEMA Conference Committee.

\section{Introduction}

The vocational education keeps growing from year to year. It can be seen from the increasing number of the vocational institutions in Indonesia, i.e 14,211 according to the data from the Ministry of Education and Culture. The average growth of vocational education is $7.5 \%$. This number is getting bigger recently since the government launched the program of "SMK BISA". On the other hand, the popularity of senior high secondary schools is declining (http://reference.data.kemdikbud.go.id/odd semester data in 2018). The development of can also be indicated from the big amount of Vocational high school (VHS) students. Nowadays, the junior high school students prefer VHS (65\%) to senior high school (Rony Windarto, 2016).

Several problems, in fact, are still encountering the implementation of vocational education in Indonesia in terms of curriculum, graduate quality, facility and learning process. These various problems have prompted the President of the Republic of Indonesia, Joko Widodo, to issue The Presidential Instruction No. 9 of 2016 concerning the revitalization of VHS for Quality Improvement and Human Resource Competitiveness of Indonesian 
Human Resources on September 9, 2016. It mandates the related ministers, governors, and the head of the National Education Standardization Body to make strategic steps based on their respective duties, functions and authorities enhance VHS.

The President also instructed to create the map of labor requirements for vocational graduates based on the VHS roadmap development. Following this, 34 governors are demanded to assist the public access for qualified vocational education services based on the potential of each region. Meanwhile, The Education and Culture Ministry has been instructed to perfect the curriculum for vocational schools to produce graduates that would meet employers' demands. In addition, the Ministry has been assigned to increase the number of vocational school teachers, as well as to improve their quality. The Research, Technology and Higher Education Ministry are also asked to accelerate the availability of vocational school teachers and develop study programs in universities to produce vocational school teachers (Directorate of VHS Development, Ministry Education and Culture, 2016).

To boost the development of vocational education with this current era, the use of information and technology must be emphasized in its progress. The information technology is growing rapidly this time and has come to the era of digital media with the support of internet connection. Through the internet, anything can be accessed anywhere, such as data entry and it can be controlled from one central place. It makes the information distribution rapidly and accurately unless the system has been running well (Ekowati, 2003). As the emerging internet technologies of spatial geographic information technology, Geographic Information System (GIS,) is a system designed to work with data that is spatially referenced or with geographic coordinates. GIS has the ability to process data and carry out certain operations by displaying and analyzing data. The GIS application is complete with various functions and strengths. The future development of GIS applications leads to Web-based applications that are expected to help users to easily find their desired locations. The use of GIS is expected to be a solution to overcome the lack of information from the prospective students related to vocational high schools and its expertise programs. By having those adequate information, they can decide the proper expertise program. Moreover, this system does not only present the information about the spatial location of the school, but also various other data that can be a crucial consideration in choosing the VHS.

The related study from Liang Wang (2008) entitled Design and Application of GIS Software Plat-form Integrating with DSS Oriented to e-Government presents new ideas for designing platform-based software on integrative SIG and DSS that are appropriate for targeting the construction of E-government in China. It introduces the integration of 
functions, methods and technical procedures at different platform levels. As the further development, Chen Tian-en, Chen Li-ping, Gao Yunbin, Wang Yanji (2009) conduct research on Spatial Decision Support System for Precision Farming Based on GIS Web Service. Furthermore, Xiaolin Lu (2009) has done a study on A Unified E-Government Information Management Platform Based on Web GIS Technology. In the similar area, Ikuho Yamada, Peter A. Rogerson, Gyoungju Lee (2009) investigates Geo-Surveillance: a GIS-based system for the detection and monitoring of spatial clusters. Meanwhile, this study focus on the introduction of software named Geo-Surveillance that combine the spatial statistical techniques and GIS routines to test spatial clustering detection and monitoring.

\section{Method and Equipment}

\subsection{Method}

This study employed Research and Development (R \& D) model. According to Sugiyono (2009), R \& D model is used to produce certain products, and test the effectiveness of the product.

The research design used waterfall model according to Pressman in developing GIS based website. The detail of the steps is presented in Figure 1 below.

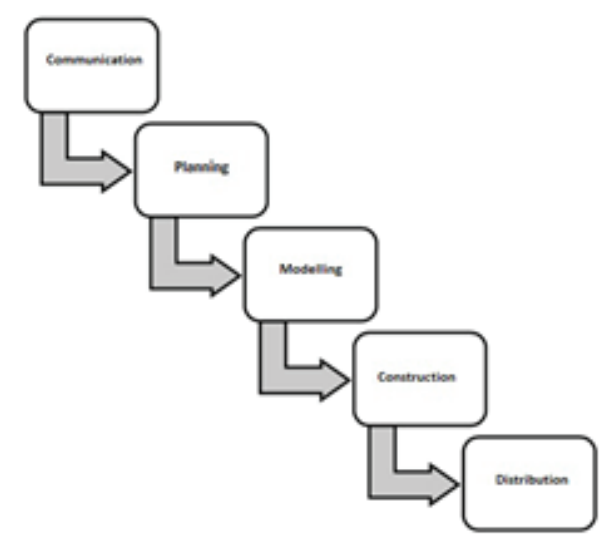

Figure 1: Research Procedure.

The sources of data in this research as the subjects to obtain the data include:

a. The ninth grade students of junior high schools as the users and the teachers as the moderator of GIS based-VHS online portal, in the case of the usability aspect.

b. The experts of programming (software developer) in case of the functionality aspect. 
c. The documentation of GIS based-VHS online portal for the aspect of reliability, efficiency, maintainability and portability.

The data collection method of this study was intended to find out an overview of the situation and problems that occur within the research area. This study was limited in the administrative area of Surakarta, Central of Java, especially the problems related to the inadequate information on VHS. The methods consisted of the following.

The interview sessions were used to gather information during the needs analysis stage. This part was carried out by having direct interviews with the students and the teachers of junior high schools as well as vocational high schools in Surakarta. The purpose of the interview is to find out the following.

a. The users' problem in searching information

b. The users' needs

C. The type of information

d. The features of the needed software

The observation was made to the object under study. It was performed to collect data during the needs analysis stage and the feasibility test of the GIS based-VHS online portal for the aspects of efficiency, reliability, maintainability and portability. By having observed, it can directly review the running system.

This technique was conducted by giving a set of statements/ questions that must be responded by the respondents. The advantages of questionnaire techniques are more efficient in case of time and suitable to be applied if the number of respondents is quite big. The questionnaires distribution was employed to test the functionality and usability of GIS based-VHS online portal.

\subsection{Equipment}

The instruments used in the quality testing of GIS based-VHS online portal referred to ISO: 9126 standard. The characteristics used in the software quality testing cover the following.

a. The Functionality Aspect. The aspect to measure the functionality aspect was the questionnaire that listed the functions of GIS based-VHS online portal which described the procedures of system use. This test of functionality aspect performed by the programming experts (software developers).

b. The Reliability Aspect. The reliability aspects were tested using the WAPT application. It was an automated software to test the performance of the website application. 
The testing was done by using 1-20 users for 10 minutes with the scenario that every 60 seconds there were 5 additional users who accessed the system. It was done to see the stability and the consistency of the measurement results or the reliability of the developed online portals.

c. The Usability Aspect. The instrument to test the usability aspect was a questionnaire of Computer Usability Satisfaction Questionnaires: Psychometric Evaluation and Instructions that was developed by IBM as the measurement standard of software usability (Lewis, 1993).

d. The Efficiency Aspect. The efficiency aspect was tested using YSlow and Gtmetrix measuring instruments that were developed by Yahoo Developer Network to measure the performance of a website page. The measured performance included the bytes of document data, number of HTTP requests, minification, GZIP compression, and score / final grade.

e. The Maintainability Aspect. The maintainability aspect was tested using the Search Engine from Semantic Design, an Automated Software Analysis System. The testing was done by collecting data on Lines of Code, Cyclomatic Complexity, Halstead Volume, and Comment Lines. The obtained data were used as the basis for calculating the Maintainability Index with the formula proposed by Coleman. The results of the Maintainability Index were compared with the maintenance category as the basis for evaluating the maintainability of the system in order to know the system maintenance.

f. The Portability Aspect. The portability aspect was tested using several different types of web browsers including Google Chrome, Mozilla Firefox, and Internet Explorer with a tool called BrowseEmAll. This tool can run a virtual web browser so that it can test the information systems with various web browsers.

The data analysis was done by using the formulas to interpret the results. It was used to calculate the variable data to examine the aspects of functionality, reliability, usability, efficiency, maintainability, and portability. The analysis employed the measurements of the questionnaire, namely the Guttman and Likert scales.

Meanwhile, The Guttman scale was used for the explicit answers. It can be made in the form of a checklist from the highest to the lowest. The use of the Guttman scale in this study with the answer of "Yes" - "No" was to test the functionality aspects of the developed portal. On the other hand, Likert scale was used to measure attitudes, opinions and perceptions of a person or group towards variables. It described variables as indicators to be used as the starting point in arranging instrument items. The items can be either statements or questions. The answer to each instrument employing Likert scale criteria of "very positive" to "very negative". 


\section{References}

[1] Dirjen Guru dan Tenaga Kependidikan. (2016, October 15). Data Pendidikan Mennegah dan Kejuaruan. Retrieved from Reference and Data of National Education: http://wwwreferensi.data.kemdikbud.go.id

[2] Ekowati, Y. (2003). Rancangan Basis Data Informasi Morbiditas Yang Berbasis. Komputer Di ISO/IEC Standard No. 9126. 2001-2004: Software engineering - Product quality; Parts 1-4.International Organization for Standardization (ISO) / International.

[3] Lewis, J. (2018, September 26). IBM computer usability satisfaction questionnaires: psy- chometric evaluation and instructions for use. Retrieved from http://drjim. Ocatch.com/usabqtr.pdf

[4] Lu, X. (2009). A Unified E-Government Information Management Platform Based on Web GIS Technology. Proceedings - 2009 International Conference on Computational Intelligence and Software Engineering, CISE 2009.

[5] Sekretariat Negara Republik Indonesia. (2016). Instruksi Presiden no.9. Revitalisasi SMK.

[6] Shan, T. C., \& Hua, W. W. (2006). Taxonomy of Java Web Applications. IEEE International Conference on e-Business Engineering.

[7] Statistik, B. P. (2018). Berita Resmi Statisting, Keadaan Ketenagakerjaan Indonesia Februari 2018. Jakarta: Badan Pusat Statistik.

[8] Sugiyono. (2012). Metode Penelitian Kuantitatif, Kualitatif, dan R\&D Cetakan V. Bandung: Alfa Bheta.

[9] Wang, L. \&. (2008). Design and Application of GIS Software Platform Integrating with DSS Oriented to E-Government. International Conference on Natural Computation, (hal. 483-487).

[10] Web-Application Development Using the Model/View/Controller Design Pattern. (2001). Enterprise Distributed Object Computing Conference, 2001. EDOC '01. (page. 118-127). Seatle: Fifth IEEE International.

[11] Windarto, Rony. (2013). Minat Siswa SMP Negeri Melanjtukan ke SMK ditinjau dari Sosial Ekonomi Keluarga di Kabupaten Bantul. Jurnal Pendidikan Vokasi.

[12] Woojong, S. (2005). Web Engineering: Principles and Techniques. USA: Idea Group Publishing. 